\title{
Study of the correlation between blood cholinesterases activity, urinary dialkyl phosphates, and the frequency of micronucleated polychromatic erythrocytes in rats exposed to disulfoton
}

\author{
Mariane Gonçalves Santos ${ }^{1}$, Ricardo Vilela Vitor ${ }^{1}$, Maurício Gustavo Nakamura ${ }^{1}$, Luana de Souza \\ Morelini $^{2}$, Rafaela Scalco Ferreira ${ }^{2}$, Alexandre Giusti Paiva ${ }^{3}$, Luciana Azevedo ${ }^{2}$, Vanessa Bergamin \\ Boralli Marques ${ }^{1}$, Isarita Martins ${ }^{1}$, Eduardo Costa Figueiredo ${ }^{1, *}$
}

\author{
${ }^{1}$ Toxicants and Drug Analysis Laboratory, LATF, Federal University of Alfenas, UNIFAL, Alfenas, Minas Gerais, \\ Brazil, ${ }^{2}$ Nutritional and Toxicological Analysis in vivo Laboratory, Federal University of Alfenas, UNIFAL, Alfenas, Minas \\ Gerais, Brazil, ${ }^{3}$ Physiological Science Laboratory, Federal University of Alfenas, UNIFAL, Alfenas, Minas Gerais, Brazil
}

\begin{abstract}
Organophosphates (OPs) are widely used as pesticides, and its urinary metabolites as well as the blood cholinesterases (ChEs) activity have been reported as possible biomarkers for the assessment of this pesticide exposure. Moreover, the OPs can induce mutagenesis, and the bone marrow micronucleus test is an efficient way to assess this chromosomal damage. This paper reports a study carried out to verify the correlation among the disulfoton exposure, blood ChEs activity, urinary diethyl thiophosphate (DETP), and diethyl dithiophosphate (DEDTP), as well as micronucleated polychromatic erythrocytes (MNPCEs) frequency. Four groups of rats $(\mathrm{n}=12)$ were exposed to disulfoton at $0,2.8,4.7$, and $6.6 \mathrm{mg} \mathrm{kg}^{-1}$ body weight. The blood ChEs activity, urinary DETP and DEDTP concentrations, and MNPCEs frequency were determined. It was observed that the plasmatic and erythrocytary ChEs activity decreased from $2.9 \%$ to $0.5 \%$ and from 35.9 to $3.3 \%$, respectively, when the disulfoton dose was increased from 0 to $6.6 \mathrm{mg} \mathrm{kg}^{-1}$ (correlation of 0.99). Urinary DETP and DEDTP concentrations, as well as the MNPCEs frequency, increased from 0 to $6.58 \mu \mathrm{g} \mathrm{mL}^{-1}$, from 0 to $0.04 \mu \mathrm{g} \mathrm{mL}^{-1}$, and from 0 to $1.4 \%$, respectively, when the disulfoton dose was increased from 0 to $6.58 \mathrm{mg} \mathrm{kg}^{-1}$ body weight.
\end{abstract}

Uniterms: Pesticides/exposure study. Organophosphate/exposure study. Disulfoton/exposure. Dialkyl phosphate/urinary excretion. Blood cholinesterase. Micronucleated polychromatic erythrocytes/frequency.

Os organofosforados (OPs) são amplamente usados como praguicidas e a atividade da colinesterase sanguínea bem como os metabólitos urinários desses praguicidas têm sido reportados como biomarcadores eficazes para avaliar casos de exposição. Além disso, os OPs podem induzir mutagênese e o teste de micronúcleo de medula óssea é uma boa alternativa para avaliar os danos cromossômicos. Esse artigo reporta um estudo sobre a correlação entre a exposição a dissulfoton, a atividade da colinesterase sanguínea, a excreção urinária de dietil tiofosfato e dietil ditiofosfato e a frequência de micronúcleos em eritrócitos policromáticos. Quatro grupos de ratos $(\mathrm{n}=12)$ foram expostos a dissulfotom nas doses de $0,2,8,4,7$, e $6,6 \mathrm{mg} \mathrm{kg}^{-1}$ de peso corpóreo. A atividade da colinesterase sanguínea as concentrações urinárias de dietil tiofosfato e dietil ditiofosfato e a frequência de micronúcleos foram determinadas. Os resultados demonstraram que as atividades da colinesterase plasmática e eritrocitária diminuíram de 2,9 para $0,5 \%$ e de 35,9 para $3,3 \%$, respectivamente, quando a dose de dissulfoton foi aumentada de 0 para $6,6 \mathrm{mg} \mathrm{kg}^{-1}$ (correlação de 0,99). As concentrações urinárias de dietil tiofosfato e dietil ditiofosfato bem como a frequência de micronúcleos aumentaram de 0 a $6,56 \mu \mathrm{g} \mathrm{mL}^{-1}, 0$ a $0.04 \mu \mathrm{g} \mathrm{mL}^{-1}$ e de 0 a $1.4 \%$, respectivamente, quando a dose de dissulfotom foi aumentada de 0 a $6,58 \mathrm{mg} \mathrm{kg}^{-1}$.

Unitermos: Pesticidas/exposição. Organofosforados/exposição. Dissulfoton/exposição. Dialquil fosfatos/ excreção urinária. Colinesterase sanguínea. Eritrócitos policromáticos micronucleados/frequência.

\footnotetext{
*Correspondence: E. C. Figueiredo. Toxicants and Drugs Analysis Laboratory, Faculty of Pharmaceutical Sciences, Federal University of Alfenas. Rua Gabriel Monteiro da Silva, 700, 37130-000 - Alfenas - MG, Brazil. E-mail: eduardocfig@yahoo.com.br
} 


\section{INTRODUCTION}

Organophosphates (OPs) are potent and effective anticholinergic insecticides and one of the largest classes of pesticides sold worldwide. They are widely and effectively used in agriculture, but to a lesser extent, in domestic pest control (Odetokun et al., 2010). Among the organophosphates, we can mention disulfoton $(O, O$-diethyl $S$-[2(ethylthio)ethyl] phosphorodithioate) (Figure 1), which is extensively used in coffee crops in Brazil. However, these compounds can be responsible for serious intoxication problems, and, for this reason, biomarkers are welcome to monitor the level of exposure to OPs, as well as the more probable effects resulting from each one.

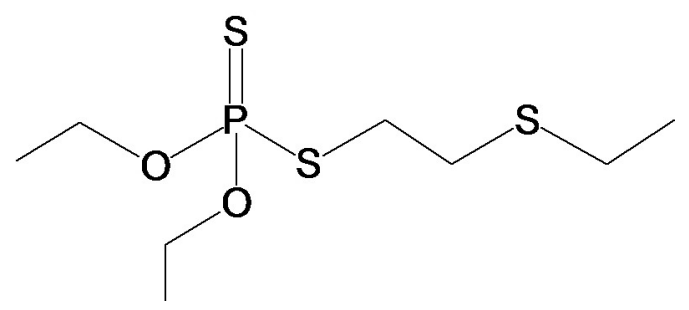

FIGURE 1 - Chemical structure of disulfoton.

Blood cholinesterases (ChEs) activity (specifically in erytrocities) has been largely used as a biomarker of OPs exposure since these pesticides inhibit these enzymes' activity in red blood cells and plasma (Yucra et al., 2006; Costa, 2008).

A simple procedure based on spectrophotometry can be efficiently employed to determine the ChEs activity (Ellman et al., 1961). On the other hand, there is a great variation in normal enzymatic activity among different individuals. Thus, the ChEs activity in the pre-exposure period should be the reference to estimate the enzymatic activity during the exposure (HSE, 2000). In addition, OPs insecticides can be biologically metabolized to dialkyl phosphates (DAPs), and these urine metabolites have also been reported as possible biomarkers to assess the OP exposure levels (Maroni, Fait, 1993; Wu et al., 2010). However, their use as biomarkers has not been regulated yet. Figure 2 shows the structures of the two most commonly measured disulfoton metabolites: diethyl thiophosphate (DETP) and diethyl dithiophosphate (DEDTP) (Bravo et al., 2002; De Alwis et al., 2009).

Another effect of the OPs is their ability to induce mutation and probably cancer. A good methodology to evaluate the mutagenic effect is the in vivo rat bone marrow micronucleus test, due to its effective assessment of both chromosomal damage and loss, induced by chemicals, as well as its simplicity and high speed in compari- son with traditional chromosome analysis (Von Ledebur, Schmid, 1973; MacGregor et al., 1987). The micronucleus can originate from acentric chromosome fragments or from whole chromosome lagging at anaphase during the division of the nucleated precursor cells. They persist in the cytoplasm during some time, and thus, may be scored at interphase in polychromatic erythrocytes (Watanabe et al., 1982; Kirsch-Volders, 1997; Cicchetti et al., 1999). An increase in the micronucleated polychromatic erythrocytes (MNPCEs) frequencies is, therefore, an indication of aneuploidy or induced clastogenicity.
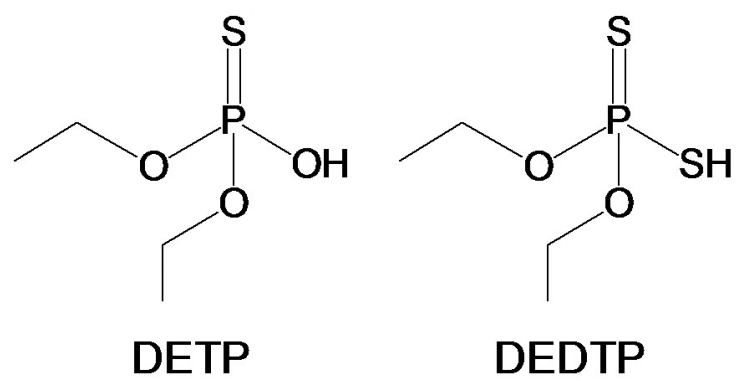

FIGURE 2 - Chemical structure of diethyl thiophosphate (DETP) and diethyl dithiophosphate (DEDTP).

As commented previously, different biomarkers have been individually studied to evaluate the exposure to OPs or the specific effects of these pesticides. However, the correlations among them, as well as the exposure doses, have not been estimated until today, and there is no classification about the efficiency of each one for monitoring the exposure. In this context, this work aimed at studying the correlation among the exposure doses, blood ChEs activities, urinary DETP and DEDTP concentrations, as well as MNPCEs frequencies in rat groups exposed to disulfoton.

\section{MATERIALS AND METHODS}

\section{Chemicals and solutions}

Acetonitrile and tetrahydrofuran (HPLC grade) were obtained from Vetec (Rio de Janeiro, Brazil). The water was obtained from a Milli-Q water purification system (Millipore, Bedford, USA). Disulfoton ( $O, O$-diethyl $S$-[2(ethylthio)ethyl]phosphorodithioate $98.6 \%$ purity) was purchased from Fluka (Buchs, Switzerland) and prepared in corn oil before each application. Stock solutions of DETP and DEDTP (both from Sigma-Aldrich, Steinheim, Germany) were prepared at $1.0 \mathrm{mg} \mathrm{L}^{-1}$ in acetonitrile, placed in an amber flask, and kept at $-20{ }^{\circ} \mathrm{C}$ for up to 30 days. Dithiobisnitrobenzoate (DTNB), acethylthiocholine (ATTC), and cyclophosphamide (CPA) were obtained from Sigma- 
Aldrich (Steinheim, Germany). 3\% (v/v) 2,3,4,5,6-pentafluorobenzyl bromide (PFBBr) (Sigma-Aldrich, Steinheim, Germany) solution was prepared in acetonitrile, daily.

\section{Study subjects and sample preparation}

The animals used in this study were handled in accordance with the Ethical Principles for Animal Research adopted by the Brazilian College of Animal Experimentation (COBEA). The protocol used here was approved by the Ethics Committee for Animal Research at the Federal University of Alfenas (process: 296/2010). Adult male rats weighing $275 \pm 30 \mathrm{~g}$ were used in the in vivo experiments. The animals were housed in metabolic cages in an experimental room under controlled conditions of temperature $\left(22 \pm 2^{\circ} \mathrm{C}\right)$, humidity $(55 \pm 10 \%)$, and 12-h light/dark cycle with ad libitum access to diet and water. The animal experiment comprised four groups with 12 rats each. Group 1 was the negative control and Groups 2, 3, and 4 received a single intraperitonial injection of disulfoton solution (Llorens et al., 1993) containing 2.8, 4.7, and $6.6 \mathrm{mg} \mathrm{kg}^{-1}$ body weight, respectively, corresponding to $30 \%, 50 \%$, and $70 \%$ of the $50 \%$ lethal dose of disulfoton in rats, (LD50 = $9.4 \mathrm{mg} \mathrm{kg}^{-1}$ body weight) (Brodeur, Dubois, 1963). For the MNPCEs test, a group of six rats was also used as positive control, in addition to the other groups, which received $30 \mathrm{mg} \mathrm{kg}^{-1}$ body weight of CPA. The DETP and DEDTP urinary concentrations were determined, for each group, in urine samples collected after $24 \mathrm{~h}$ of the disulfoton application. Urine samples were submitted to a molecularly imprinted solid-phase extraction (MISPE) followed by derivatization with $\mathrm{PFBBr}$ and analyzed using gas chromatography mass spectrometry (GC-MS), as described by Santos et al. (2012). DETP and DEDTP concentrations were corrected by the urine density (Molyneux, 1964). Animals were sacrificed by decapitation, $24 \mathrm{~h}$ after the treatment, and all the blood was collected to evaluate the ChEs activities by the Ellman modified method (Ellman et al., 1961). The bone marrow was processed immediately after the decapitation, and the mutagenicity studies were carried out using the bone marrow micronucleus test, according to MacGregor et al. (1987) protocol.

\section{Instrumental}

A gas chromatography mass spectrometer (GC-MS) model QP-2010 from Shimadzu ${ }^{\circledR}$ Corporation (Kyoto, Japan) equipped with a RTx ${ }^{\circledR}-5 \mathrm{MS}(30 \mathrm{~m} \times 0.25 \mathrm{~mm}$ i.d. $\times 0.25 \mu \mathrm{m}$ ) capillary column (RESTEC, Bellefonte, USA) was used to determinate DETP and DEDTP urinary concentrations. Blood cholinesterase activities were determined using a UV-VIS Biomate 5 (Thermo Electron Corporation, Rochester, USA) spectrophotometer operating at a wavelength of $430 \mathrm{~nm}$. An Eclipse $50 \mathrm{i}$ (Nikon, Melville, USA) microscope was used to perform the MNPCEs counting.

\section{Statistical analysis}

An analysis of variance (ANOVA) followed by independent $t$ tests were used for statistical analysis of the results for ChEs activities and DAPs levels. The MNPCEs frequencies between the treated groups and their respective controls were compared using Chi-square test $\left(\chi^{2}\right)$ (Dragano et al., 2010). All results were considered statistically significant if the $p$ values obtained were $\leq 0.05$.

\section{RESULTS AND DISCUSSION}

Measurements of erythrocyte ChEs activity have been used to indicate the exposure to OPs (HSE, 2000; Costa, 2008). However, the enzyme activities' measurements may not be sufficient to infer about the exposure levels to OPs, as these enzymes can also be inhibited in the absence of OPs. Moreover, the major problem is the difficulty to be able to measure very small decreases in the enzyme's activity compared to the normal levels (Cocker et al., 2002). Furthermore, the best correlations are only obtained when the ChEs activities, during the exposure, are compared with the pre-exposure values of the same individuals. Thus, we consider it important to investigate the possible correlations among OP exposure doses with other potential biomarkers such as the urinary metabolites of OPs (e.g. DETP and DEDTP), as well as the DNA lesions by the increase in the MNPCEs frequencies.

For this purpose, different doses of disulfoton were administered in rat groups as described in the section, "Study subjects and sample preparation". Table 1 shows that significant differences were observed among all exposed groups and the negative control for the plasma ChEs activity. Nevertheless, there were no significant differences in the plasma ChEs activity between both groups exposed to 2.8 and $4.7 \mathrm{mg} \mathrm{kg}^{-1} \mathrm{~b}$.w, whereas statistical differences between the group exposed to $6.8 \mathrm{mg} \mathrm{kg}^{-1}$ and the other groups (exposed to 2.8 and $4.7 \mathrm{mg} \mathrm{kg}^{-1}$ ) were observed. For the erythrocyte ChEs activity, statistical differences were observed among all the groups. It was also observed that, at the lowest dose of disulfoton $\left(2.8 \mathrm{mg} \mathrm{kg}^{-1}\right)$, there was a decrease of ca. $50 \%$ in the erythrocyte ChEs activity, indicating that this biomarker is more sensible than the plasma ChEs activity. The erythrocyte ChEs activity can also be considered a better biomarker than the plasma ChEs ac- 
TABLE 1 - Activity of plasma and erythrocytes ChEs, urinary concentration of DETP and DEDTP and frequencies of MNPCE in the bone marrow of rats exposed to disulfoton in different exposure doses

\begin{tabular}{|c|c|c|c|c|c|c|}
\hline Treatment & $\begin{array}{c}\text { Rat } \\
\text { Number }\end{array}$ & $\begin{array}{c}\text { Plasma ChE } \\
(\%)\end{array}$ & $\begin{array}{c}\text { Erythrocyte } \mathrm{ChE} \\
(\%)\end{array}$ & $\begin{array}{c}\text { DETP } \\
\left(\mu \mathrm{g} \mathrm{mL}^{-1}\right)\end{array}$ & $\begin{array}{l}\text { DEDTP } \\
\left(\mu \mathrm{g} \mathrm{mL}^{-1}\right)\end{array}$ & $\mathrm{MN}$ bone borrow* $\%$ \\
\hline $\begin{array}{l}\text { Negative control group } \\
\text { (not exposure) }\end{array}$ & 12 & $2.85 \pm 0.08$ & $35.86 \pm 3.17$ & $<0.010$ & $<0.007$ & $0.48 \pm 0.17$ \\
\hline $\begin{array}{l}\text { Group } 1 \text { (exposure } \\
\text { to disulfoton at } \\
\left.2.8 \mathrm{mg} \mathrm{kg}^{-1} \mathrm{~b} . \mathrm{w}\right) \\
\end{array}$ & 12 & $0.85 \pm 0.08$ & $18.75 \pm 2.60$ & $1.18 \pm 0.14$ & $0.013 \pm 0.001$ & $0.62 \pm 0.18$ \\
\hline $\begin{array}{l}\text { Group } 2 \text { (exposure } \\
\text { to disulfoton at } \\
\left.4.7 \mathrm{mg} \mathrm{kg}^{-1} \mathrm{~b} . \mathrm{w}\right)\end{array}$ & 12 & $0.74 \pm 0.10$ & $11.80 \pm 1.07$ & $2.40 \pm 0.31$ & $0.04 \pm 0.006$ & $1.20 \pm 0.20$ \\
\hline $\begin{array}{l}\text { Group } 3 \text { (exposure } \\
\text { to disulfoton at } \\
\left.6.8 \mathrm{mg} \mathrm{kg}^{-1} \mathrm{~b} . \mathrm{w}\right) \\
\end{array}$ & 12 & $0.52 \pm 0.05$ & $3.30 \pm 0.32$ & $6.58 \pm 0.96$ & $0.11 \pm 0.015$ & $1.40 \pm 0.20$ \\
\hline
\end{tabular}

tivity due to the larger correlation coefficient as shown in Figure 3A. These results highlight the importance of the erythrocyte ChEs activity, as the decrease of the plasma ChEs activity is not always related to the exposure to OPs (Cocker et al., 2002). On the other hand, it is known that the erythrocyte ChEs activity is basically influenced by OPs, with less interference of other factors.

The main metabolic route of OPs in mammals produces metabolites that are excreted in urine. These compounds can be considered biomarker candidates, mainly due to their high specificity, once that their concentrations increase basically after exposure to OPs (Cocker et al., 2002). However, it is important to highlight that their use as biomarkers has not been regulated yet. Therefore, DETP and DEDTP were determined in animal's urine exposed to different doses. As can be seen in Table 1, DEDTP concentrations were smaller than DETP concentrations. According to Oglobline et al. (2001), DEDTP is quickly metabolized to the corresponding monosulphated and oxidized metabolites yielding low urinary levels. Figure $3 \mathrm{~B}$ shows that there is an exponential increase in the DETP and DEDTP concentrations when the disulfoton doses are increased. Perhaps disulfoton, like other organophosphates such as chlorpyrifos, can cause bioactivation of CYP2B6, CYP1A2, CYP2A6, CYP2C9, CYP2C19, and CYP3A4, resulting in their exponential increase for higher doses (Sams, Cocker, Lennard, 2004). When the doses of disulfoton are less than $4.7 \mathrm{mg} \mathrm{kg}^{-1}$ b.w., a satisfactory linear correlation was obtained for both analytes $(r=0.993$ and $r=0.952$, respectively, for DETP and DEDTP), attesting that both metabolites are adequate to express the intoxication levels.

The mutagenic ability of disulfoton in acute exposure was also assessed by MNPCEs frequencies (Table 1).
The sensitivity was shown by the positive group's response, which used the mutagenic agent (CPA) and displayed significant increases in MNPCEs frequencies when compared to the negative control group. The results showed that all groups exposed to disulfoton presented MNPCEs frequencies larger than that spontaneously generated by the negative control group. In this way, all dose levels can be considered mutagenic. Additionally, the lesion caused by this pesticide was lower than that caused by the mutagenic agent CPA, an inactive pro-drug that induces its therapeutic anti-tumor activity after being metabolized to acrolein by the hepatic cytochrome P450 enzymes (eg. 3A4, 4A5), similarly to the OPs (Liu et al., 2012). Besides, it was possible to observe that the MNPCEs frequencies increased proportionally with the doses, resulting in a linear tendency, as demonstrated in Figure $3 \mathrm{C}$. These results are comparable with the paper from Mohant et al. (2011), who observed a linear relationship between exposure dose and DNA damage $(r=0.84)$ by using comet assay in fingerlings exposed to the phorate. These DNA damages were probably caused by electrophile and nucleophile compounds as well as by some primary metabolites such as oxons that interfere in the structural integrity of biomolecules, namely, proteins and nucleic acids (Caprino, Togna, 1998). Thus, the increase of the pesticide dose may result in more DNA damage, favoring the cancer process in the exposed individuals.

Overall, our study demonstrates that plasma and erythrocyte ChEs activities reflected the relationship between dose and effect. However, the erythrocyte ChEs activity resulted in better correlation and sensitivity. Additionally, a satisfactory correlation between exposure 

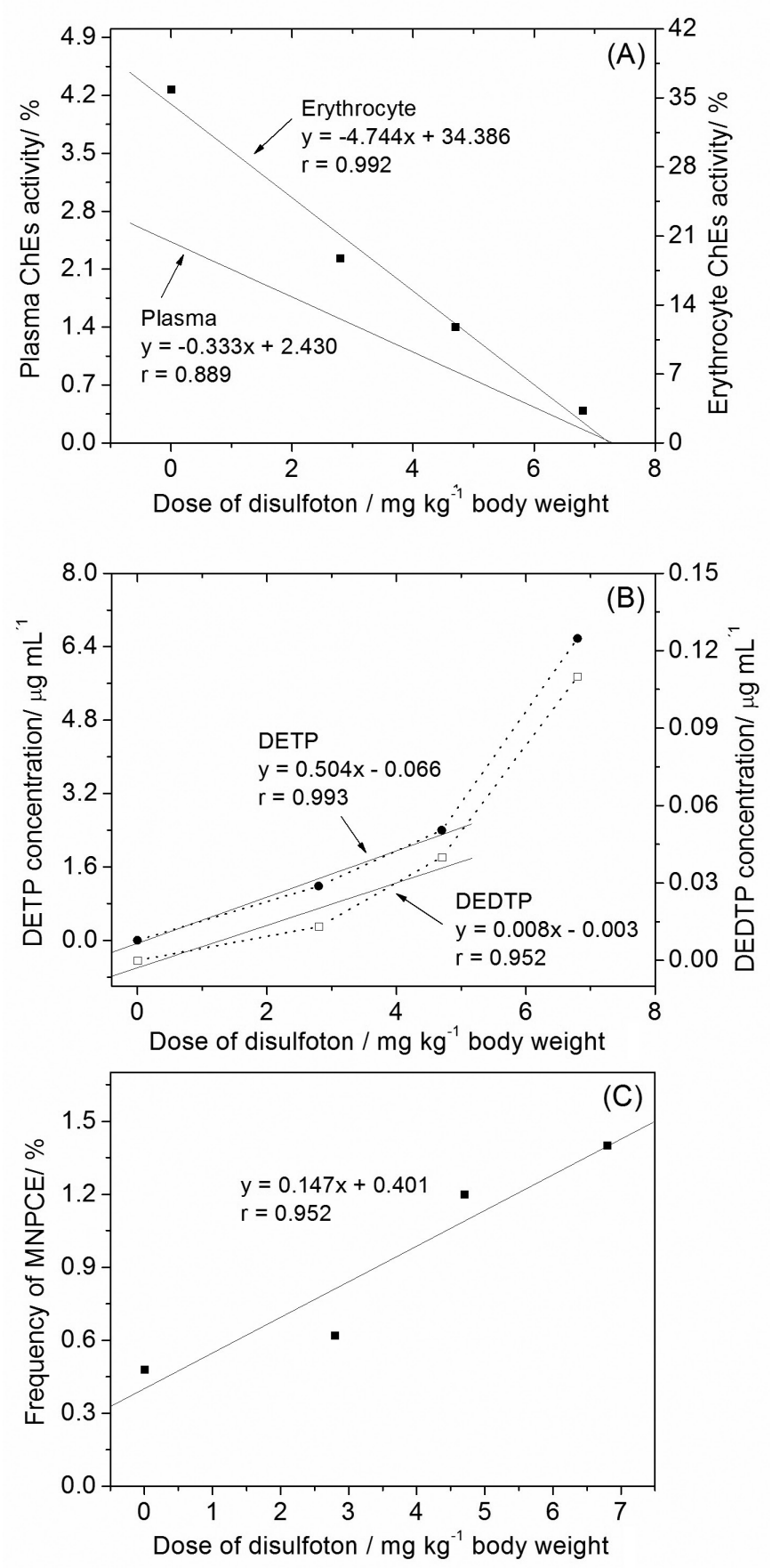

FIGURE 3 - Effect of the disulfoton doses in the plasma and erythrocyte ChEs (A), in the urinary concentration of DETP and DEDTP (B) and in the frequency of MNPCEs (C).

dose $\left(<4.7 \mathrm{mg} \mathrm{kg}^{-1}\right.$ b.w) and the urinary metabolites concentrations was also observed, particularly for DETP (high sensitivity). Furthermore, the measurement of urinary DAPs metabolites is less invasive and logistically easier. Finally, for doses higher than $2.8 \mathrm{mg} \mathrm{kg}^{-1} \mathrm{~b} . \mathrm{w}$, it is possible to suggest that, like other OPs, the disulfoton causes mutagenicity in vivo, even in an acute exposure (Bagchi et al., 2005), a fact especially important for victims of accidental ingestion or attempted suicide.

\section{ACKNOWLEDGMENTS}

The authors thank the Fundação de Amparo a Pesquisa do Estado de Minas Gerais (FAPEMIG, Belo Horizonte, Brazil) - projects CDS - APQ-01323-09, CDS - APQ-01612-10 and CDS-APQ-02458-11, the Conselho Nacional de Desenvolvimento Científico e Tecnológico (CNPq, Brasília, Brazil) and the Coordenação de Aperfeiçoamento de Pessoal de Nível Superior (CAPES, Brasília, Brazil) for financial support.

\section{REFERENCES}

AMERICAN CONFERENCE OF GOVERNMENTAL INDUSTRIAL HYGIENISTS. ACGIH. Documentation of the threshold limit values and biological exposure indices. 6.ed. Cincinnati, OH, 1991. p.534-535.

BAGCHI, M.; ZAFRA, S.; BAGCHI, D. DNA Damage, gene expression, and carcinogenesis by organophosphates and carbamates. In: GUPTA, R.C. (Ed.). Toxicology of organophosphate and carbamate compounds. Hopkinsville: Elsevier, 2005. p.533-548.

BRAVO, R.; DRISKELL, W.J.; WHITEHEAD JR., R.D.; NEEDHAM, L.L.; BARR, D.B. Quantitation of dialkyl phosphate metabolites of organophosphate pesticides in human urine using GC-MS-MS with isotopic internal standards. J. Anal. Toxicol., v.26, p.245-252, 2002.

CAPRINO, L.; TOGNA, G.I., Potential health effects of gasoline and its constituents: a review of current literature (1990-1997) on toxicological data. Environ. Health Perspect., v.106, p.115-125, 1998.

CICCHETTI, R.; BARI, M.; ARGENTIN, G. Induction of micronuclei in bone marrow by two pesticides and their differentiation with CREST staining: an in vivo study in mice. Mutat. Res., v.439, p.239-248, 1999.

COCKER, J.; MASON, H.J.; GARFITT, S.J.; JONES, K. Biological monitoring of exposure to organophosphate pesticides. Toxicol. Lett., v.134, p.97-103, 2002.

COSTA, L.G. Toxic effects of pesticides. In: KLAASSEN, C.D.; AMDUR, M.O.; DOULL, J. (Eds.). Casarett and Doull's Toxicology. The basic sciences of poisons. New York: Macmillan, 2008. Cap. xx, p.892. 
DEALWIS, G.K.H.; NEEDHAM, L.L.; BARR, D.B. Automated solid phase extraction, on-support derivatization and isotope dilution-GC/MS method for the detection of urinary dialkyl phosphates in humans. Talanta, v.77, p.1063-1067, 2009.

DRAGANO, N.R.V.; VENANCIO, V.P.; PAULA, F.B.A.; LUCIA, F.D.; FONSECA, M.J.O; AZEVEDO, L. Influence of marolo (Annonacrassiflora Mart.) pulp intake on the modulation of mutagenic/antimutagenic processes and its action on oxidative stress in vivo. Plant Foods Hum. Nutr., v.65, p.319-325, 2010.

ELLMAN, G.L.; COURTNEY, K.D.; ANDRS, V.; FEATHERSTONE, R.M. A new and rapid colorimetric determination of acetylcholinesterase activity. Biochem. Pharmacol., v.7, p.88-95, 1961.

HEALTH AND SAFETY EXECUTIVE. HSE. Medical Aspects of work-related exposure to organophosphates 3.ed. Sudbury: HSE, 2000. (Guidance note MS17). Available at: http://www.aerotoxic.org/download/docs/reports_and_ evidence/MS17.pdf. Accessed on: 23 nov. 2011.

KIRSCH-VOLDERS, M. Towards a validation of the micronucleus test. Mutat. Res., v.392, p.1-4, 1997.

LLORENS, J.; CROFTON, K.M.; TILSON, H.A.; ALI, S.F.; MUNDY, W.R. Characterization of disulfoton-induced behavioral and neurochemical effects following repeated exposure. Fundam. Appl.Toxicol,. v.20, p.163-169, 1993.

MACGREGOR, J.T.; HEDDLE, J.A.; HITE, M.; MARGOLIN, B.H.; RAMEL, C.; SALAMONE, M.F.; TICE, R.R.; WILD, D. Guidelines for the conduct of micronucleus assays in mammalian bone marrow erythrocytes. Mutat. Res., v.189, p.103-112, 1987.

LIU, F.; LI, X-L.; LIN, T.; HE, D-W.; WEI, G-H.; LIU, J-H.; LI, L-S. The cyclophosphamide metabolite, acrolein, induces cytoskeletal changes and oxidative stress in Sertoli cells. Mol. Biol. Rep., v.39, p.493-500, 2012.

MARONI, M.; FAIT, A., Health effects in man from long-term exposure to pesticides: a review of the literature. Toxicology, v.78, p.1975-1991, 1993.

MOHANTY, G.; MOHANTY, J.; NAYAK, A.K.; MOHANTY, S.; DUTTA, S.K. Application of comet assay in the study of DNA damage and recovery in rohu (Labeorohita) fingerlings after an exposure to phorate, an organophosphate pesticide. Ecotoxicology, v.20, p.283-292, 2011.
MOLYNEUX, M.K.B. Use of single urine samples for the assessment of lead absortion. Brit. J. Industr. Med., v.21, p.203-209, 1964.

ODETOKUN, M.S.; MONTESANO, M.A.; WEERASEKERA, G.; WHITEHEAD JR., R.D.; NEEDHAM, L.L.; BARR, D.B. Quantification of dialkylphosphate metabolites of organophosphorus insecticides in human urine using 96well plate sample preparation and high-performance liquid chromatography-electrospray ionization-tandem mass spectrometry. J. Chromatogr. B, v.27, p.2567-2574, 2010.

OGLOBLINE, A.N.; ELIMELAKH, H.; TATTAM, B.; GEYER, R.; O’DONNELL, G.E.; Holder, G. Negative ion chemical ionization GC/MS-MS analysis of dialkylphosphate metabolites of organophosphate pesticides in urine of nonoccupationally exposed subjects. Analyst, v.126, p.10371041, 2001.

SAMS, C.; COCKER, J.; LENNARD, M.S. Biotransformation of chlorpyrifos and diazinon by human liver microsomes and recombinant human cytochrome p450s (CYP). Xenobiotica, v.34, p.861-873, 2004.

VON LEDEBUR, M.; SCHMID, W. The micronucleus test: methodological aspects. Mutat. Res., v.19, p.109-117, 1973.

WATANABE, M.; HONDA, S.; HAYASHI, M.; MATSUDA, T. Mutagenic effects of combinations of chemical carcinogens and environmental pollutants in mice as shown by the micronucleus test. Mutat. Res., v.97, p.43-48, 1982.

WU, C.; LIU, P.,; ZHENG, L.; CHEN, J.; ZHOU, Z. GC-FPD measurement of urinary dialkylphosphate metabolites of organophosphorous pesticides as pentafluorobenzyl derivatives in occupationally exposed workers and in a general population in Shanghai (China). J. Chromatogr. B, v.878, p.2575-2581, 2010.

YUCRA, S.; STEENLAND, K.; CHUNG, A.; CHOQUE, F.; GONZALES, G.F. Dialkyl phosphate metabolites of organophosphorus in applicators of agricultural pesticides in Majes - Arequipa (Peru). J. Occup. Med. Toxicol., v.1, p.27-34, 2006.

Received for publication on $25^{\text {th }}$ June 2012 Accepted for publication on $25^{\text {th }}$ October 2012 